Київський національний університет ім. Тараса Шевченка E-mail: AntonDanik@gmail.com, saa@univ.kiev.ua

\title{
Алгоритмічне послаблення впливу розсіяного випромінювання на рентгенівські зображення як альтернатива апаратним методам
}

\author{
Представлено академіком НАН України О.О. Кришталем
}

Розроблений авторами алгоритм послаблення впливу розсіяного випромінювання на рентгенівсъкі зображення порівняний з двома найефективнішими апаратними методами: збільшення повітряного проміжку та застосування протирозсіювальних растрів. За допомогою числового моделювання показано, що простота та ефективність техніки маніпуляції величиною повітряного проміжку нівелюється збільшенням розмірів сканера і вимогами до детектора. Типовий протирозсіювальний растр із коефіиієнтом 12 відсіює розсіяне випромінювання з ефективністю десятиметрового повітряного проміжку, але вимагає для ивого більшу на 50 \% експозицію і дозове навантаження на пацієнта. Запропонована алгоритмічна компенсація забезпечує характеристики на рівні середніх апаратних засобів без збільшення дозового навантаження $i$ додаткових апаратних вимог.

Ключові слова: рентгенівське зображення, розсіяне рентгенівське випромінювання, симуляція методом Монте-Карло, протирозсіювальний растр, алгоритмічна компенсація, протирозсіювальний проміжок.

Рентгенівська діагностика грунтується на ідеї отримання тіньових зображень об'єкта в рентгенівських променях. Рентгенівські апарати мають джерело рентгенівського випромінювання та детектор, чутливий до випромінювання джерела. Обстежуваний об'єкт розміщується між джерелом і детектором таким чином, що випромінювання, яке випромінює джерело, проходить через об’єм об’єкта і досягає детектора. Завдяки взаємодії із речовиною об’єкта, фотони рентгенівського випромінювання можуть зазнати поглинання, розсіювання або вільно пройти крізь об’єкт (рис. 1). Первинне випромінювання - це частина початкового випромінювання джерела, яке пройшло крізь об'єкт без взаємодії із речовиною об'єкта. Це випромінювання створює корисне зображення внутрішньої структури об'єкта. Випромінювання розсіяних рентгенівських фотонів, в основному спричинене процесами роз-

Ц и т в в ан н я: Даник А.Ю., Судаков О.О. Алгоритмічне послаблення впливу розсіяного випромінювання на рентгенівські зображення як альтернатива апаратним методам. Допов. Наи. акад. наук Укр. 2021. № 4. C. 114-122. https://doi.org/10.15407/dopovidi2021.04.114 
сіяння Комптона та Релея, переважно є неколінеарним щодо первинного випромінювання [1]. Таким чином, розсіювання спотворює результуюче рентгенівське зображення, погіршуючи його контрастність і різкість, додаючи додатковий шум і нерівномірний фон. Шкала Хаунсфілда також спотворюється. Вирішення проблеми впливу розсіяного випромінювання на якість рентгенівських зображень без підвищення дозового навантаження є важливим завданням, особливо для потреб медичної візуалізації.

\section{1. Послаблення розсіяного випромі-} нювання. Підходи до вирішення проблеми розсіяного випромінювання на рентгенівських зображеннях можна розділити на дві групи: методи послаблення розсіяного випромінювання, основною метою яких є зменшення кількості розсіяного випромінювання, що бере участь у формуванні рентгенівського зображення; і компенса-
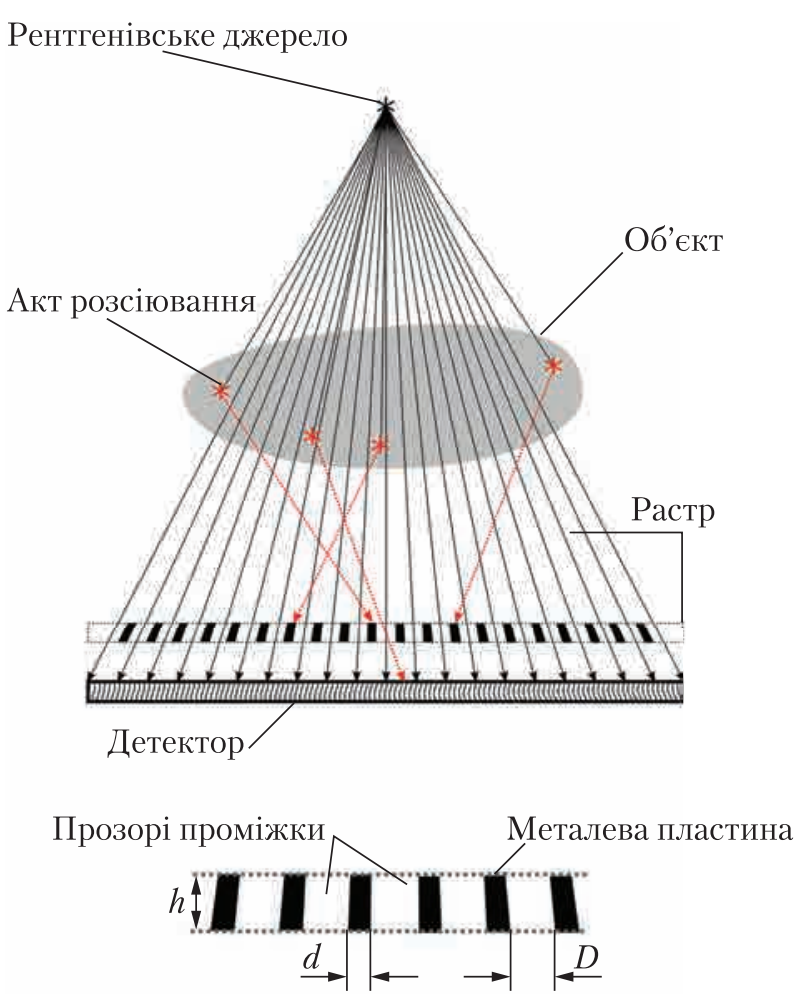

Puc. 1. Протирозсіювальний растр ційні методи, основною метою яких є корекція рентгенівського зображення, утвореного під впливом розсіяного випромінювання. У цій роботі порівняно методи першої групи із розробленим авторами методом другої групи. Основним критерієм порівняння методів є параметр “вибірковості” ( $\xi$ ) [2]. Цей параметр визначається співвідношеннями між розсіяним і первинним випромінюванням із застосуванням методу послаблення $\left(\delta^{\prime}\right)$ та без нього $(\delta)$ таким чином: $\xi=\delta^{\prime} / \delta$.

Протирозсіювальний растр. Протирозсіювальний растр - це матриця металевих пластин (наприклад, із свинцю), орієнтована на “фокус” джерела рентгенівського випромінювання (див. рис. 1) так, щоб мінімізувати поглинання первинного випромінювання та максимізувати поглинання розсіяного випромінювання, яке неколінеарне до первинного. Властивості растрів визначають матеріали пластин і міжпластинних проміжків. Основними характеристиками растра (див. рис. 1) є: фокусна відстань $F$; товщина пластин $D$; товщина зазорів $d$; висота $h$; частота, або кількість пластин на $1 \mathrm{cм}, N=1 /(d+D)$, коефіцієнт $r=h / D$. Зазначені параметри (особливо коефіцієнт растра) визначають прозорість растра $T_{p}$ щодо первинного та $T_{s}$ щодо розсіяного випромінювання. На характеристики прозорості растра також вливають конфігурація рентгенівського апарата, колімування растра щодо рентгенівського апарата (пластини мають бути орієнтовані на фокус джерела рентгенівського випромінювання) і структурні особливості досліджуваного об'єкта. В термінах прозорості вибірковість набуває такого вигляду: $\xi=\delta / \delta^{\prime}=T_{p} / T_{s}$.

Протирозсіювальний растр сильно поглинає розсіяне випромінювання, але водночас первинне випромінювання також поглинається. Для опису того, скільки всього випроміню- 
вання пройшло через растр, використовується коефіцієнт пропускання суми первинного та розсіяного випромінювання $T_{t}$. Цей параметр сильно залежить від досліджуваного об'єкта і в деяких випадках у $T_{t}$ переважає первинне випромінювання, в інших - розсіяне. Втрати інтенсивності випромінювання, що потрапляє на детектор, доводиться компенсувати збільшенням інтенсивності джерела рентгенівського випромінювання (або збільшенням часу експозиції), що призводить до пропорційного збільшення поглиненої пацієнтом дози. Збільшення інтенсивності джерела рентгенівського випромінювання або збільшення дози описується фактором Бакі: $B=1 / T_{t}$.

Типові параметри растра для рентгенівської трубки 90 кэВ та акрилового фантома 20 см [3] наведені у таблиці.

Незважаючи на сильне придушення розсіяного випромінювання, протирозсіювальний растр має кілька недоліків, що спонукає у багатьох випадках шукати альтернативу. Внаслідок застосування растра значно зменшується сигнал (див. коефіцієнт Бакі в таблиці). Компенсація втрат вимагає збільшення інтенсивності рентгенівського опромінення, що зумовлює пропорційне збільшення поглинутої досліджуваним обєктом дози опромінення і є вкрай небажаним для медичного обстеження. Растр, як і досліджуваний об'єкт, бере участь у формуванні зображення, і отримане рентгенівське зображення може містити елементи растра. Застосування растра вимагає хорошої колімації рентгенівської системи. Фокуси джерела рентгенівського випромінювання та растра повинні збігатися, інакше прозорість растра погіршується і виникають артефакти. Растр збільшує масу та розміри системи, що в деяких випадках є дуже небажаним, наприклад, у разі комп'ютерної томографії (КТ). У випадку останнього покоління КТ-сканерів складно побудувати детектор із растром, бо детектор у таких системах повинен бути чутливим до рентгенівських променів у межах широкого кута.

Повітряний проміжок. Іншим способом зменшення кількості розсіяного випромінювання, що потрапляє на детектор, є збільшення відстані (розміру повітряного зазору) між досліджуваним об’єктом і детектором. Цю ідею схематично можна пояснити на прикладі “точкового” джерела рентгенівського випромінювання, як показано на рис. 2. Метод заснований на ідеї, що інтенсивність випромінювання від такого джерела зменшується обернено пропорційно квадрату відстані від джерела. У разі невеликого “повітряного зазору” (контактна експозиція) співвідношення між розсіяним та первинним випромінюванням визначається як $\delta=C\left(F / a_{c}\right)^{2}$, де $C-$ коефіцієнт пропорційності, $a_{c}-$ відстань між об'єктом і детектором, $F$ - відстань між умовним фокусом і детектором. У разі збільшення повітряного зазору (експозиція зі збільшенням) це співвідношення $\delta^{\prime}=C\left(F / a_{z}\right)^{2}$, де $a_{z}-$ відстань між об'єктом і детектором. Вибірковість повітряного проміжку дається простим виразом $\xi=\delta / \delta^{\prime}=\left(a_{z} / a_{c}\right)^{2}$. Як видно зі схеми (див. рис. 2, $\left.a\right)$, у випадку конусного променя (точкове джерело) збільшення повітряного проміжку призводить до збільшення зобра-

Типові характеристики растрів

\begin{tabular}{|r|c|c|c|c|c|}
\hline$r$ & $T_{s}$ & $T_{p}$ & $\Xi$ & $T_{t}$ & $B$ \\
\hline $6: 1$ & 0,194 & 0,623 & 3,21 & 0,310 & 3,23 \\
$12: 1$ & 0,078 & 0,533 & 6,83 & 0,197 & 5,07 \\
$16: 1$ & 0,050 & 0,506 & 10,12 & 0,154 & 6,50 \\
\hline
\end{tabular}

116 ження об'єкта, яке визначається коефіцієнтами збільшення таким чином: $m_{c}=F /\left(F-a_{c}\right)$; $m_{z}=F /\left(F-a_{z}\right)$. Тоді вибірковість через коефіцієнти збільшення дорівнює

$$
\xi=\left(\frac{\left(m_{z}-1\right) m_{c}}{\left(m_{c}-1\right) m_{z}}\right)^{2} .
$$

ISSN 1025-6415. Dopoz. Nac. akad. nauk Ukr. 2021. № 4 

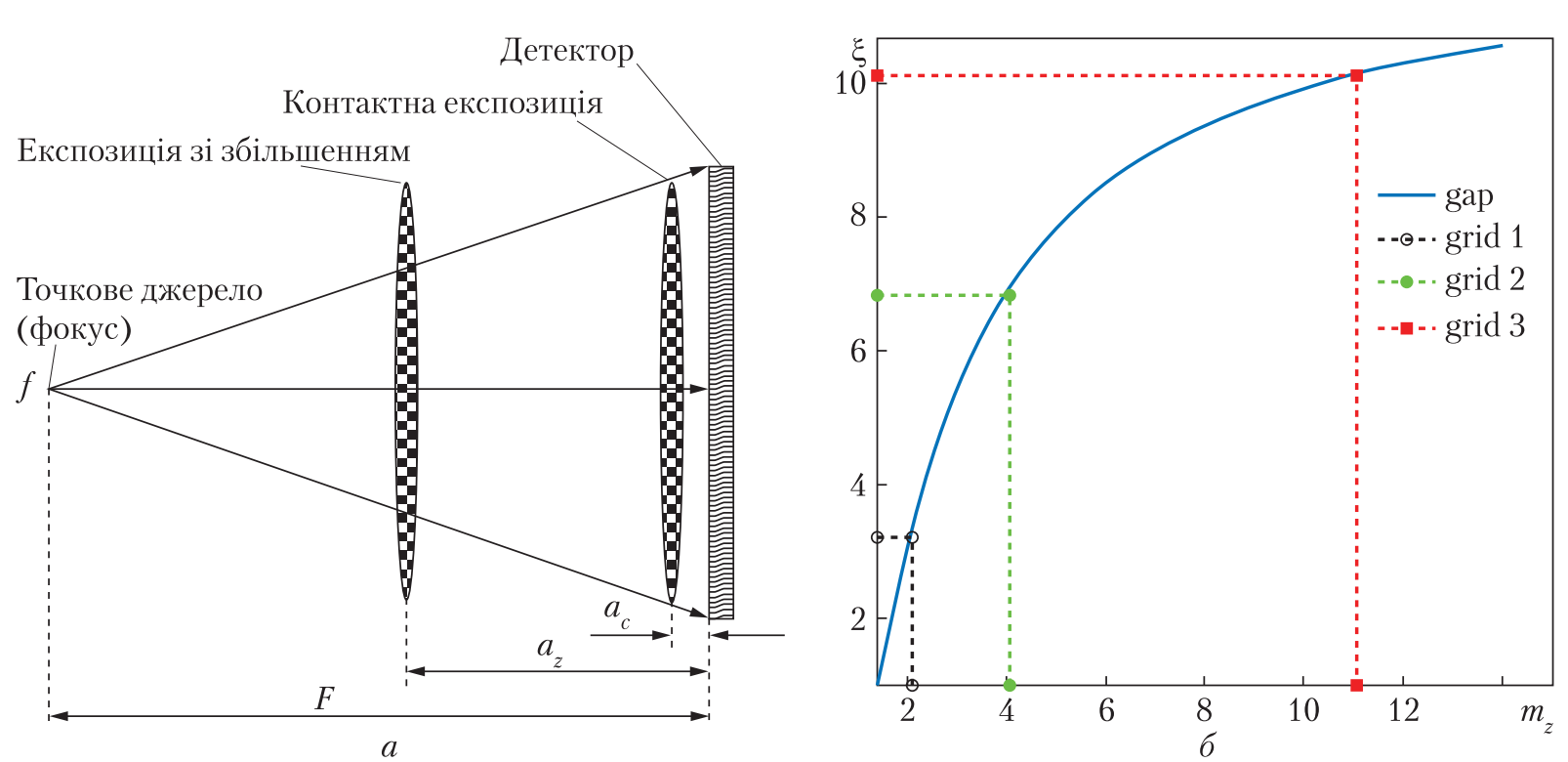

Puc. 2. Повітряний проміжок: $a$ - схема точкового джерела, $\sigma$ - вибірковість як функція збільшення $\left(m_{c}=1,4\right)$

Порівнюючи ефективність растра та повітряного проміжку, легко переконатися, що растр забезпечує таку саму вибірковість, як і десятиразове збільшення повітряного проміжку. Водночас повітряний проміжок позбавлений деяких недоліків растрів: первинне випромінювання послаблюється на порядки менше (в основному завдяки проходженню крізь товстий шар повітря). Отже, доза менша, результуюче рентгенівське зображення позбавлене елементів растра, немає необхідності у точній колімації растра із рентгенівським апаратом. Проте цей метод має очевидний недолік - у більшості випадків важко зробити достатньо великий повітряний проміжок (особливо у випадку КТ).

Загалом, згідно з даними наукових джерел, досить великий повітряний проміжок дає кращі результати, ніж застосування протирозсіювального растра. У рентгенографії органів грудної клітки [4] збільшення повітряного проміжку приводить до збільшення контрасту для задньо-передньої проєкції з тією ж дозою і до зменшення дози із незначним зниженням контрасту у разі бічної проєкції порівняно із застосуванням протирозсіювального растра. У дослідженнях із цефалометричної рентгенографії [5] повітряний проміжок порівняно з растром приводить до кращої вибірковості та до покращення співвідношення сигнал/шум і дозу вдалося зменшити більш ніж удвічі.

Алгоритмічна компенсащія. Авторами цієї роботи був розроблений алгоритм математичної обробки рентгенівських зображень для компенсації розсіяного випромінювання без використання апаратних засобів, описаних вище [6, 7]. Рентгенівське зображення ( $M$ ) 3 високою точністю можна описати за допомогою рівняння

$$
\sum_{i} M_{i}(x, y)=\sum_{i}\left[P_{i}(x, y)+\left\{P_{i} * K_{i}\right\}(x, y)\right]
$$

де $i$ нумерує області зображення з приблизно однаковим розсіюванням; $x, y-$ координати у площині зображення, $P$ - області зображення первинного випромінювання; $K-$ 

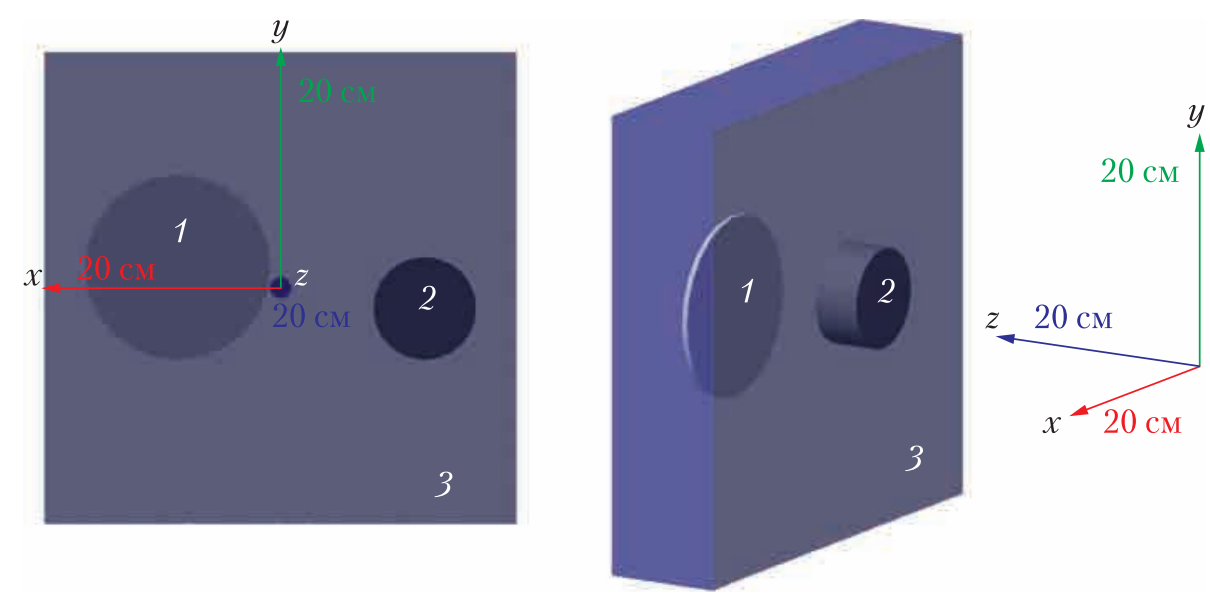

Puc. 3. Математичний фантом: 1 - циліндр з кальцію, 2 - циліндр 3 повітря, 3 - паралелепіпед з води (прямокутний акваріум)

функції ядер розсіювання для кожної області. Це рівняння розв'язується ітераційно для знаходження розподілу первинного випромінювання на основі відомих функцій ядра розсіювання та виміряного зображення. Визначення ядер розсіювання відбувається за допомогою реалістичного математичного моделювання проходження рентгенівського випромінювання через речовину методом Монте-Карло для математичних фантомів. Розбиття результуючого зображення на області та прив'язка ядер розсіювання до кожної області здійснюється за допомогою класифікатора на основі машини опорних векторів. Було показано, що розбиття на 8-13 областей забезпечує відновлення 95 \% контрасту первинного випромінювання [6]. Алгоритмічна компенсація може бути застосована на установках малого розміру, не вимагає протирозсіювальних растрів і повітряних проміжків, а також не збільшує дозове навантаження. Головним недоліком цього підходу є можливі нестійкості під час розв'язання оберненої задачі, а також відсутність повної інформації про досліджуваний об’єкт, що потенційно зменшує точність компенсації.

2. Числове моделювання. Для перевірки і порівняння вищенаведених оцінок було проведено серію числових моделювань взаємодії рентгенівського випромінювання з тестовим математичним фантомом за наявності протирозсіювального растра, з варіюванням розміру повітряного проміжку між об'єктом та детектором і з використанням алгоритмічної компенсації.

Математичний фантом (рис. 3) складається з двох циліндрів з кальцію та з повітря, які занурені в акваріум з водою. Розміри акваріума $400 \times 400 \times 100$ мм. Циліндр з кальцію має товщину 5 мм, циліндр 3 повітря - 40 мм.

Моделювання здійснено методом Монте-Карло із використанням програмного пакета GATE [8] на базі ресурсів обчислювального центру Київського національного університету ім. Тараса Шевченка [9]. Джерело рентгенівського випромінювання опромінювало тестовий фантом паралельним пучком інтенсивністю 10000000000 фотонів у секунду із середньою енергією фотона $0,0407 \mathrm{MeB}$ (із реалістичним спектром). Кожна симуляція враховувала найважливіші в термінах досліджуваних явищ фізичні процеси: розсіювання за Комптоном та Релеєм, фотоефект і синхротронне випромінювання за схемою [6]. Перша 

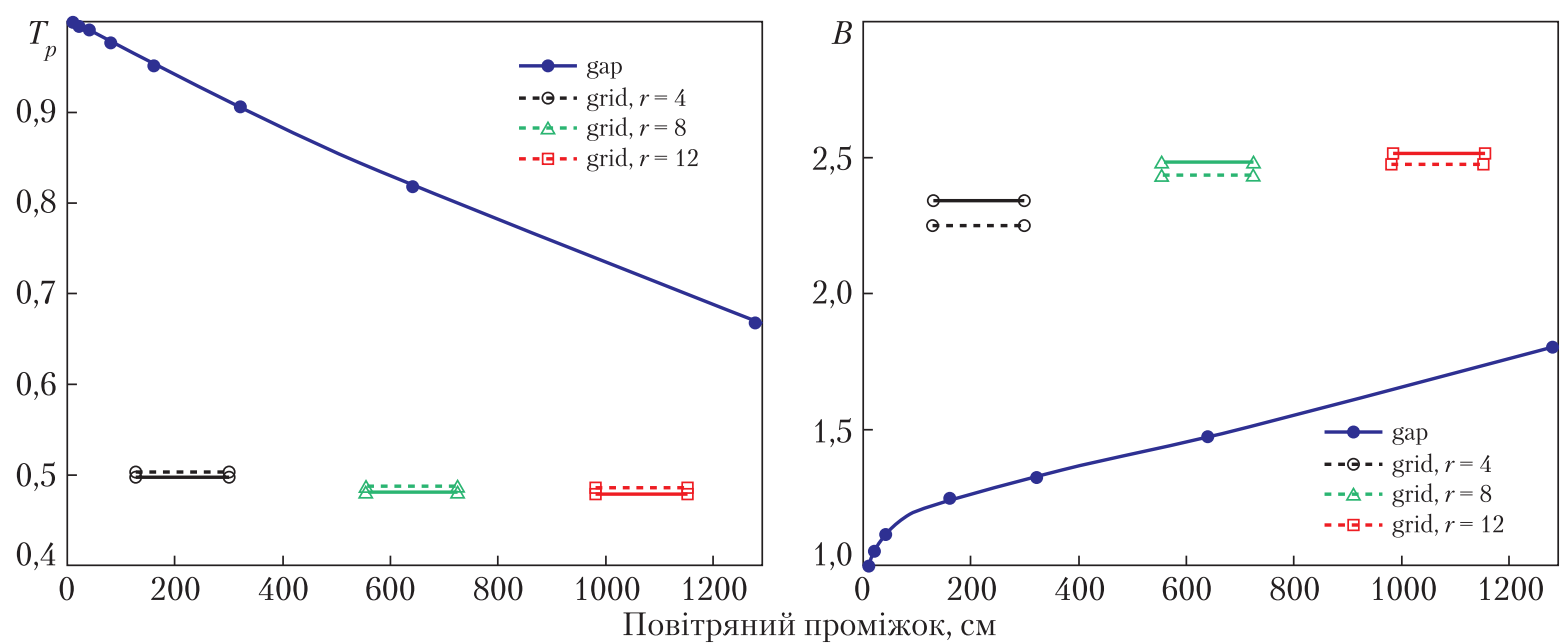

$a$
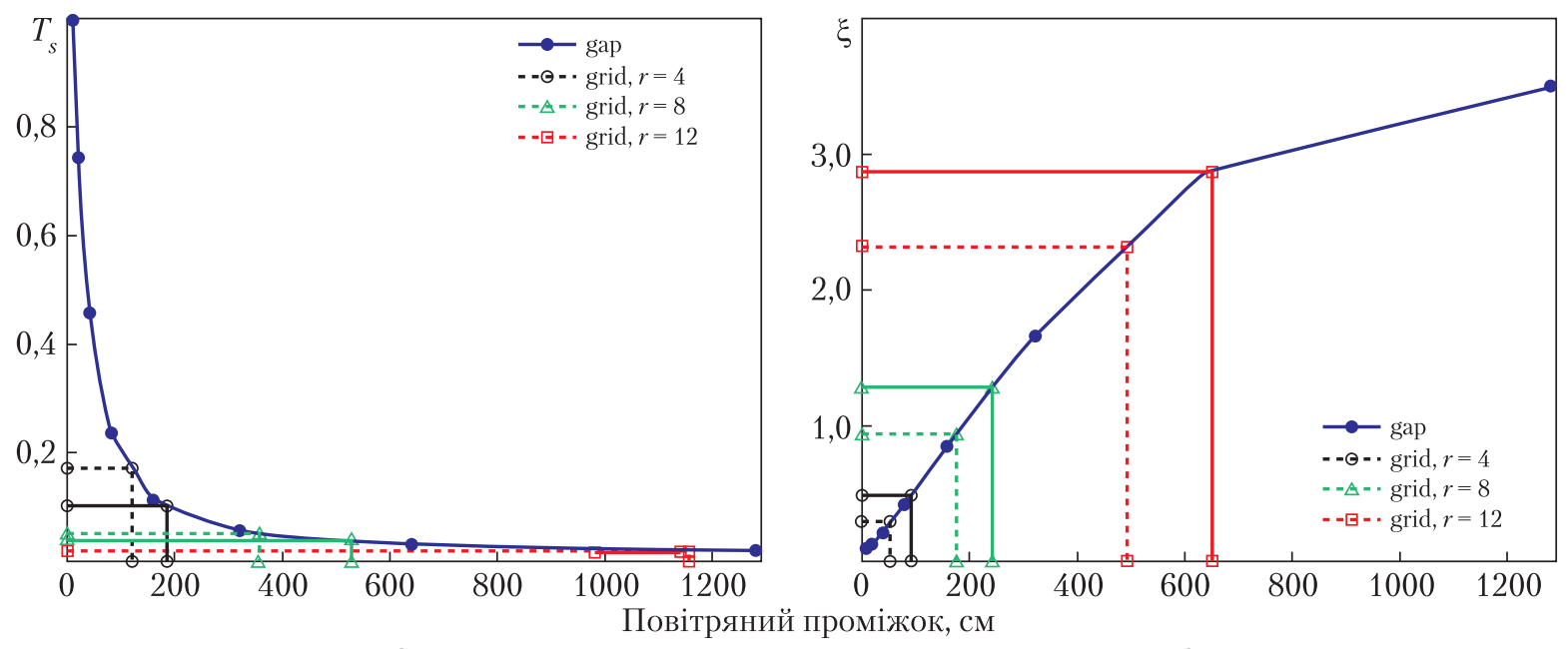

B
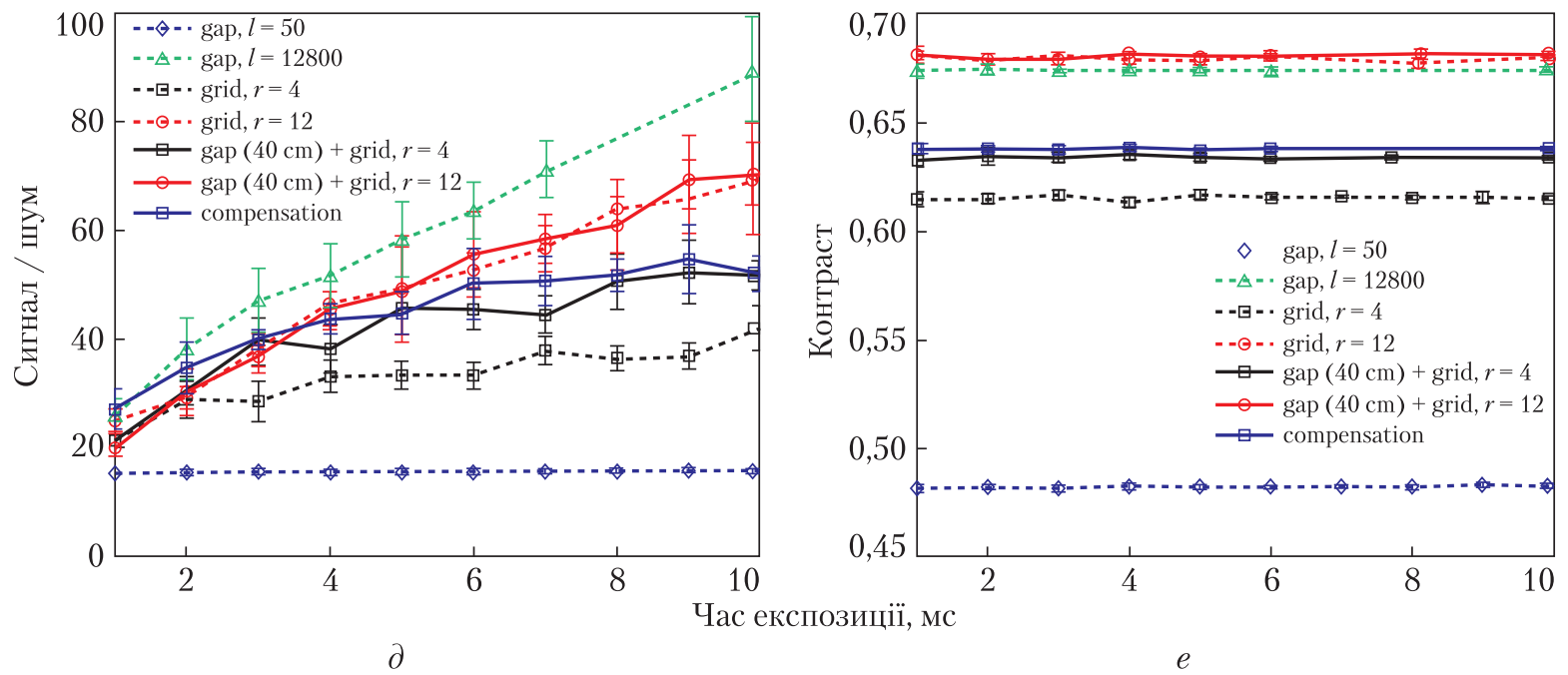

$\boldsymbol{P u c . 4}$. Порівняння різних значень повітряного проміжку та растра з малим повітряним проміжком 5 см (штрихова лінія), 40 см (суцільна лінія); $a$ - прозорість за первинним випромінюванням; $\sigma$ - фактор Бакі; в - прозорість за розсіяним випромінюванням; $\imath-$ вибірковість; $\partial-$ за співвідношенням сигнал/ шум для води; $e-$ за контрастом між кальцієвим та повітряним циліндрами 
серія числових моделювань виконана з експозицією 1 мс з використанням різних растрів (позн. grid) з $N=60 \mathrm{~cm}^{-1}, d=49$ мкм, $D=120$ мкм, $r=4,8,12$ і для різних значень повітряного проміжку (позн. gap) від 5 см до 12 м. Друга серія симуляцій виконувалася з різними експозиціями (1-10 мс) для крайніх значень повітряного проміжку 5 см та 12 м і коефіцієнтів растра 4 та 12. 3 растром використовувався малий повітряний проміжок 5 та 40 см.

Результати першої серії симуляцій наведені на рис. 4. Збільшення повітряного проміжку закономірно сильно зменшує кількість розсіяного випромінювання, що потрапляє на детектор (див. рис. 4, в), і помірно зменшує кількість первинного випромінювання (див. рис. $4, a)$ за рахунок поглинання в повітрі. Збільшення параметру растра $r$ зумовлює водночас краще послаблення розсіяного випромінювання та небажане зростання фактору Бакі.

Для отримання достовірних результатів кожна симуляція другої серії повторювалася сім разів, формуючи довірчі інтервали, які, як видно з рис. 4, чітко розмежовують групи методів послаблення розсіяного випромінювання за параметрами якості рентгенівського зображення: співвідношення сигнал/шум та контраст. У разі достатнього пригнічення розсіяного випромінювання істотним фактором шуму в зображенні стають статистичні флуктуації випромінювання, що попадає на детектор. Співвідношення сигнал/шум (SNR) за відсутності розсіяного випромінювання для однорідного об'єкта має залежати від експозиції за законом квадратного кореня [1]. Рентгенівські зображення, отримані з найменшим повітряним проміжком (5 см), були опрацьовані із застосуванням алгоритму компенсації впливу розсіяного випромінювання на рентгенівські зображення (compensation), запропонованого у попередніх роботах [6, 7].

Растр із найбільшим значенням $r$ покращує зображення на рівні трохи гірше від найбільшого повітряного проміжку (12 м). Додавання до растра відносно невеликого повітряного проміжку ( 40 см замість 5 см) значно покращило результат. У цілому великий повітряний проміжок здатний добре послабити розсіяне випромінювання, покращуючи результуюче рентгенівське зображення, що досягається завдяки вибірковості, яка сягає значень більше 10. Хороший растр здатен повністю замінити повітряний проміжок, зменшуючи розміри сканера, але ціною в рази більшого фактору Бакі, що компенсується пропорційним підвищенням дозового навантаження. Компенсаційний алгоритм добре себе показав, забезпечивши результат із якістю посередині між двома розглянутими растрами та з фактором Бакі на рівні найменшого повітряного проміжку (тобто 1 - оскільки вихідним зображенням для алгоритму слугували зображення, отримані із найменшим повітряним проміжком).

На практиці пропонується комбінувати розглянуті підходи для пошуку оптимального за дозою та розмірами рішення. Істотно покращити результат можна, якщо зменшити поглинання рентгенівського випромінювання у “повітряному проміжку” - наприклад, розрідивши повітря або ж замінивши його на газ з малим атомним номером.

3. Висновки. Великі повітряні проміжки фільтрують розсіяне випромінювання так само добре, як високоякісний протирозсіювальний растр. Водночас метод повітряного проміжку позбавлений деяких недоліків растра: первинне випромінювання послаблюється значно менше (в основному за рахунок поглинання повітрям), а отже, і дозове навантаження пацієнта менше (приблизно вдвічі); на отриманому рентгенівському зображенні немає зображення растра; колімація всієї системи простіша і немає необхідності в додаткових витратах на протирозсіювальний растр. Попри усі зазначені переваги методу, застосування по- 
вітряних проміжків понад 1 м у ряді випадків неможливе (КТ) або позбавлене практичної цінності (джерела рентгенівського випромінювання, що використовуються, зокрема, у медичних сканерах, створюють конічний промінь, що у разі великих значень повітряного проміжку призводить до непрактично сильного збільшення результуючого зображення, а компенсація цього ефекту звужуванням рентгенівських пучків потребуватиме ще й збільшення відстані між джерелом рентгенівського випромінювання та обстежуваним об'єктом). Методи алгоритмічної компенсації розсіювання забезпечують найменше дозове навантаження на пацієнта за інших характеристик на рівні середніх величин растрів і повітряних проміжків. Для практики оптимальним буде комбінування повітряного проміжку із растром і методами алгоритмічної компенсації впливу розсіяного випромінювання на сформоване рентгенівське зображення [6].

Автори висловлюють подяку Украӥнській начіональній грід-інфраструктурі [8] та інформаційно-обчислювальному центру Київського національного університету ім. Тараса Шевченка за надані обчилювальні потужності.

\section{ЦИТОВАНА ЛІТЕРАТУРА}

1. Monnin P., Verdun F.R., Bosmans H., Rodríguez Pérez S., Marshall N.W. A comprehensive model for x-ray projection imaging system efficiency and image quality characterization in the presence of scattered radiation. Phys. Med. Biol. 2017. 62, № 14. P. 5691-5722. https://doi.org/10.1088/1361-6560/aa75bc

2. Мазуров А.И., Потрахов Н.Н. Влияние рассеянного рентгеновского излучения на качество изображения и методы его подавления. Биотехносфера. 2012. № 3-4.С. 10-14.

3. Mizuta M., Sanada S., Akazawa H., Kasai T., Abe S., Ikeno Y., Mitou S. Comparison of anti-scatter grids for digital imaging with use of a direct-conversion flat-panel detector. Radiol. Phys. Technol. 2012. 5, № 1. P. 4652. https://doi.org/10.1007/s12194-011-0134-1

4. Gould R.G., Hale J. Control of scattered radiation by air gap techniques: applications to chest radiography. Am. J. Roentgenol. 1974. 121, № 1. P. 109-118. https://doi.org/10.2214/ajr.122.1.109

5. Tsuji Y., Araki K., Endo A., Funahashi I., Okano T. Scatter radiation and the effects of air gaps in cephalometric radiography. Oral Radiol. 2006. 22, № 1. P. 7-13. https://doi.org/10.1007/s11282-006-0038-7

6. Danyk A.Y., Sudakov O.O. Optimized estimation of scattered radiation for X-ray images improvement: realistic simulation. Radioelectron. Commun. Syst. 2020. 63, № 8. P. 387-397. https://doi.org/10.3103/ S0735272720080014

7. Danyk A., Radchenko S., Netreba A., Sudakov O. Using clustering analysis for determination of scattering kernels in X-ray imaging. Intelligent data acquisition and advanced computing systems: technology and applications (IDAACS): Proceedings of the 10th IEEE International conference (Metz, France, 18-21 Sept. 2019), Vol. 1. Metz, 2019. P. 211-215. https://doi.org/10.1109/IDAACS.2019.8924353

8. Jan S., Santin G., Strul D., Staelens S., Assié K., Autret D., Avner S., Barbier R., Bardiès M., Bloomfield P.M., Brasse D., Breton V., Bruyndonckx P., Buvat I., Chatziioannou A.F., Choi Y., Chung Y.H., Comtat C., Donnarieix D., Ferrer L., Glick S.J., Groiselle C.J., Guez D., Honore P.F., Kerhoas-Cavata S., Kirov A.S., Kohli V., Koole M., Krieguer M., van der Laan D. J., Lamare F., Largeron G., Lartizien C., Lazaro D., Maas M.C., Maigne L., Mayet F., Melot F., Merheb C., Pennacchio E., Perez J., Pietrzyk U., Rannou F.R., Rey M., Schaart D.R., Schmidtlein C.R., Simon L., Song T.Y., Vieira J.M., Visvikis D., Van de Walle R., Wieërs E., Morel C. GATE: a simulation toolkit for PET and SPECT. Phys. Med. Biol. 2004. 49, № 19. P. 4543-4561. https://doi. org/10.1088/0031-9155/49/19/007

9. Sudakov O., Kononov M., Sliusar Ie., Salnikov A. User clients for working with medical images in Ukrainian Grid infrastructure. Intelligent data acquisition and advanced computing systems (IDAACS): Proceedings of the 7th IEEE International conference (Berlin, Germany, 12-14 Sept. 2013), Vol. 2. Berlin, 2013. P. 705-710. https://doi.org/10.1109/IDAACS.2013.6663016

Надійшло до редакції 17.05.2021 


\section{REFERENCES}

1. Monnin, P., Verdun, F. R., Bosmans, H., Rodríguez Pérez, S. \& Marshall, N. W. (2017). Comprehensive model for $x$-ray projection imaging system efficiency and image quality characterization in the presence of scattered radiation. Phys. Med. Biol., 62, No. 14, p. 5691-5722. https://doi.org/10.1088/1361-6560/aa75bc

2. Mazurov, A. I. \& Potrahov, N. N. (2012). Effect of scattered X-ray radiation on image quality and compensation method of these effects. Biotehnosfera, No. 3-4, pp. 10-14 (in Russian).

3. Mizuta, M., Sanada, S., Akazawa, H., Kasai, T., Abe, S., Ikeno, Y. \& Mitou, S. (2012). Comparison of antiscatter grids for digital imaging with use of a direct-conversion flat-panel detector. Radiol. Phys. Technol., 5, No. 1, p. 46-52. https://doi.org/10.1007/s12194-011-0134-1

4. Gould, R. G. \& Hale, J. (1974). Control of scattered radiation by air gap techniques: applications to chest radiography. Am. J. Roentgenol., 121, No. 1, p. 109-118. https://doi.org/10.2214/ajr.122.1.109

5. Tsuji, Y., Araki, K., Endo, A., Funahashi, I. \& Okano, T. (2006). Scatter radiation and the effects of air gaps in cephalometric radiography. Oral Radiol., 22, No. 1, pp. 7-13. https://doi.org/10.1007/s11282-006-0038-7

6. Danyk, A. Y. \& Sudakov, O. O. (2020). Optimized estimation of scattered radiation for X-ray images improvement: realistic simulation. Radioelectron. Commun. Syst., 63, No. 8, p. 387-397. https://doi.org/10.3103/ S0735272720080014

7. Danyk, A., Radchenko, S., Netreba, A. \& Sudakov, O. (2019, September). Using clustering analysis for determination of scattering kernels in X-ray imaging. Proceedings of the 10th IEEE International Conference on Intelligent data acquisition and advanced computing systems: technology and applications (IDAACS), Vol. 1 (pp. 211-215), Metz. https://doi.org/10.1109/IDAACS.2019.8924353

8. Jan, S., Santin, G., Strul, D., Staelens, S., Assié, K., Autret, D., Avner, S., Barbier, R., Bardiès, M., Bloomfield, P. M., Brasse, D., Breton, V., Bruyndonckx, P., Buvat, I., Chatziioannou, A. F., Choi, Y., Chung, Y. H., Comtat, C., Donnarieix, D., Ferrer, L., Glick, S. J., Groiselle, C. J., Guez, D., Honore, P. F., Kerhoas-Cavata, S., Kirov, A. S., Kohli, V., Koole, M., Krieguer, M., van der Laan, D. J., Lamare, F., Largeron, G., Lartizien, C., Lazaro, D., Maas, M. C., Maigne, L., Mayet, F., Melot, F., Merheb, C., Pennacchio, E., Perez, J., Pietrzyk, U., Rannou, F. R., Rey, M., Schaart, D. R., Schmidtlein, C. R., Simon, L., Song, T. Y., Vieira, J. M., Visvikis, D., Van de Walle, R., Wieërs, E. \& Morel, C. (2004). GATE: a simulation toolkit for PET and SPECT. Phys. Med. Biol., 49, No. 19, p. 4543-4561. https://doi.org/10.1088/0031-9155/49/19/007

9. Sudakov, O., Kononov, M., Sliusar, Ie. \& Salnikov, A. (2013, September). User clients for working with medical images in Ukrainian Grid infrastructure. Proceedings of the 7th IEEE International Conference Intelligent data acquisition and advanced computing systems (IDAACS), Vol. 2 (pp. 705-710), Berlin. https://doi. org/10.1109/IDAACS.2013.6663016

Received 17.05.2021

A.Y. Danyk, https://orcid.org/0000-0002-9201-0067

O.O. Sudakov, https://orcid.org/0000-0002-6588-1801

Taras Shevchenko National University of Kyiv

E-mail: AntonDanik@gmail.com, saa@univ.kiev.ua

\section{SCATTERED X-RAY RADIATION ALGORITHMIC COMPENSATION PROCEDURE IN THE X-RAY IMAGING AS AN ALTERNATIVE TO HARDWARE METHODS}

Scattered X-ray radiation compensation algorithm proposed by authors is tested and compared with the most effective hardware methods: air-gap variation, anti-scatter grids. With the help of a numerical simulation, the simplicity and efficiency of the air-gap manipulation technique are shown to be contrasted by the side effects of this method: dramatic scanner and detector size increment. Typical antiscatter grid with $r=12$ attenuates scattered radiation with an efficiency of 10 meter air gap requiring $50 \%$ more exposition and dose. The algorithmic compensation proposed by the authors provides the compensation at the level of the average hardware method but does not require an extra dose.

Keywords: X-ray image, scattered X-ray radiation, Monte-Carlo simulation, antiscatter grid, algorithmic compensation, antiscatter gap. 